\title{
Evaluation through a simulation model of nutrient exports in fast-growing southern European pine stands in relation to thinning intensity and harvesting operations
}

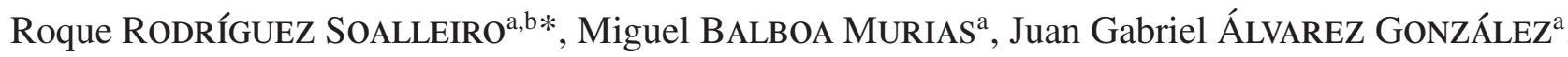 \\ Agustín MERINO GARCÍA ${ }^{\mathrm{a}}$ \\ ${ }^{a}$ Unidade de Xestión Forestal Sostible, Universidad de Santiago de Compostela, Escuela Politécnica Superior, Campus Universitario, \\ 27002 Lugo, Spain \\ ${ }^{\mathrm{b}}$ Current address: University of Wales, School of Agricultural and Forest Sciences, Bangor, UK
}

(Received 19 June 2006; accepted 25 October 2006)

\begin{abstract}
The effects on nutrient exports of a range of thinning regimes for maritime pine and radiata pine plantations in northern Spain were simulated in this study. Growth models, tree biomass equations and nutrient concentration in tree fractions were used simultaneously to calculate the amounts of $\mathrm{N}, \mathrm{P}, \mathrm{K}, \mathrm{Ca}$ and $\mathrm{Mg}$ removed and left in the logging residues for five thinning intensities, five site indexes and four harvesting scenarios for each species, considering the whole rotation. A more intense thinning regime decreases the total amount of nutrients exported and increases the proportion of nutrients returned to the soil before the clearfell, being a more progressive system of extracting nutrients from the ecosystem. A substantial amount of nutrients are located in the crown fractions and the bark, making desirable the harvesting of debarked logs. The results allow the calculation of fertilization needs to avoid the depletion of soil nutrient capital in a variety of silvicultural situations.
\end{abstract}

thinning / nutrition / growth model / Pinus radiata / Pinus pinaster

\begin{abstract}
Résumé - Évaluation grâce à un modèle de simulation des exportations de nutriments dans des peuplements européens de pins à croissance rapide en relation avec l'intensité d'éclaircie et les opérations de récolte. Les effets d'une série de régimes d'éclaircie, sur les exportations d'éléments minéraux par des plantations de pin maritime et de pin radiata au nord de l'Espagne, ont été simulés dans cette étude. L'utilisation simultanée de modèles de croissance, d'équations de biomasse et de concentrations moyennes des éléments minéraux pour chacune des parties de l'arbre a permis de calculer les quantités de $\mathrm{N}, \mathrm{P}, \mathrm{K}, \mathrm{Ca}$ et $\mathrm{Mg}$ exportées et laissées comme résidus pour cinq régimes d'éclaircie, cinq classes de productivité et quatre scénarios de récolte, en prenant en compte toute la durée de la révolution. Le régime d'éclaircie la plus forte réduit la quantité totale d'éléments exportés et augmente la proportion des éléments retournés au sol avant la coupe à blanc, c'est un système plus progressif d'extraction des éléments minéraux de l'écosystème. Une quantité substantielle d'éléments minéraux est localisée dans les différentes parties de la cime et de l'écorce, rendant souhaitable la récolte de troncs écorcés. Les résultats obtenus permettent le calcul de la fertilisation nécessaire pour éviter la réduction du capital nutritionnel des sols dans différentes situations sylvicoles.
\end{abstract}

éclaircie / modèles de croissance / Pinus radiata / Pinus pinaster

\section{INTRODUCTION}

The sustainability of forest ecosystems depends on the balance between inputs and output of nutrients, so the export of nutrients due to management operations and harvesting should not deplete existing soil stores or exceed natural inputs $[14,34]$. Among other effects, thinning and harvesting operations imply biomass and nutrient exports, which can lead to decreased reserves of soil-available limiting nutrients $[15,19,32]$.

Complex models of nutrient dynamics involve budgets and feedbacks among litterfall, retranslocation, tree growth, root uptake and decomposition while aboveground processes are directly related to tree growth. Simpler modelling ap-

*Corresponding author: roquers@lugo.usc.es proaches have been used to describe nutrients dynamics of tree biomass [7]. In this way, the use of growth models as well as compatible systems of disaggregation and nutrient calculation could be an available tool to extrapolate short term changes in nutrient dynamics to a whole rotation time scale [21].

Several studies have considered the evaluation of nutrient exports in a limited number of experimental pine plantations plots under different scenarios of harvesting regimes [27]. The high ratios between nutrients exported by harvesting and available soil stores indicate the instability of $\mathrm{P}, \mathrm{Ca}$ and $\mathrm{Mg}$ over the long term, which is consistent with frequent deficiencies and the consequent negative effect on tree growth $[45,57]$. Thus, intensive exploitation of these plantations may too result in negative budgets $[11,27]$. For the same south-Atlantic European area, other studies dealt with the mineralization of 
Table I. Descriptive statistics for trees and stands analyzed for biomass equations of maritime pine and radiata pine.

\begin{tabular}{llcccccc}
\hline Statistic & Species & $d$ & $h$ & $\bar{h}$ & $H o$ & $N$ & $d g$ \\
\hline \multirow{2}{*}{ Average } & Pinus pinaster & 22.9 & 15.1 & 19.3 & 20.5 & 771 & 33.2 \\
& Pinus radiata & 20.2 & 19.9 & 20.7 & 22.2 & 1226 & 20.6 \\
\hline \multirow{2}{*}{ Maximum } & Pinus pinaster & 49.1 & 23.8 & 21.6 & 23.8 & 955 & 40.7 \\
& Pinus radiata & 40.2 & 29.5 & 25.1 & 28.1 & 1696 & 34.6 \\
\hline \multirow{2}{*}{ Minimum } & Pinus pinaster & 5.2 & 7.1 & 15.6 & 16.3 & 396 & 27.7 \\
& Pinus radiata & 8.0 & 10.1 & 14.1 & 16.9 & 411 & 14.5 \\
\hline \multirow{2}{*}{ S.D. } & Pinus pinaster & 11.6 & 5.2 & 2.7 & 2.8 & 209 & 4.5 \\
& Pinus radiata & 7.1 & 4.8 & 3.1 & 4.0 & 379 & 6.0 \\
\hline \multirow{2}{*}{ V.C. } & Pinus pinaster & 50.5 & 34.3 & 13.9 & 13.7 & 27 & 13.5 \\
& Pinus radiata & 35.2 & 24.1 & 15.0 & 18.0 & 31 & 29.4 \\
\hline \multirow{2}{*}{} & & & & & & &
\end{tabular}

S.D. is the standard deviation, V.C. coefficient of variation (\%), $d$ diameter at breast height $(\mathrm{cm}), h$ total height $(\mathrm{m}), \bar{h}$ mean height (m), Ho dominant height (m), $N$ stocking density (stems ha ${ }^{-1}$ ) and $d g$ mean square diameter $(\mathrm{cm})$.

organic matter and nutrient dynamics after thinning or clearcut of a single radiate pine stand $[33,36]$. There is still a need to consider, for a broad range of thinning regimes and site productivities, the evaluation of nutrient exports and returned as brash considering the whole rotation period. This would help to evaluate in each case, if the soil capital of the site to be planted is known, the nutrient budget associated to a particular thinning regime for this site productivity class, and in the end the fertilization regime to be applied [9].

The aim of the present study was to calculate the accumulation and the export of nutrients over time in Pinus pinaster (maritime pine) and Pinus radiata (radiata pine) stands under a range of silvicultural alternatives, harvesting scenarios and stand productivities that are common in South Europe, and relate this values to mean soil nutrient capitals.

\section{MATERIAL AND METHODS}

\subsection{Tree biomass equations and nutrient contents}

Biomass equations for radiata pine and maritime pine recorded by Balboa et al. [4] were used in our simulations. To fit these weighted biomass equations, a total of 54 radiata pine and 125 maritime pine trees were destructively sampled in sixteen pure even-aged pine stands ( 9 for radiata pine and 7 for maritime pine), which were randomly selected after stratifying a network of permanent sample plots by site quality, to include a representative range for Northwestern Spain. Table I shows descriptive statistics for trees and stands analyzed for biomass equations. No clear differences in nutrient concentrations among sites that need to be incorporated into the models were observed. Above-ground biomass was separated and weighted in the field and then in the laboratory into needles, twigs (diameter, $d$, less than $0.5 \mathrm{~cm}$ at the insertion), thin branches ( $d$ from 0.5 to $2 \mathrm{~cm}$ ), thick branches ( $d$ from 2 to $7 \mathrm{~cm}$ ), stem bark and stem wood (debarked logs with a thin-end diameter of $7 \mathrm{~cm}$ ). Representative composite samples of all tree components were taken to determine the dry biomass (constant weight at $65^{\circ} \mathrm{C}$ ) and the dry weight ratios of tree components. Non-linear equations were fitted to relate dry weight components to tree and stand variables (see Tab. II), using nonlinear seemingly unrelated regression (NSUR) [35].

A total of 1074 multiple samples from trees felled for biomass were analyzed for nutrient content, broadening the sample obtained in previous studies [27]. The samples were obtained from an average of 11 trees per site, with a total number of 179 samples per biomass component. For each stem, $3 \mathrm{~cm}$ thick disks were sampled at three heights along the bole: one at the base of the tree, one at the top of the merchantable stem and another located halfway between these two. The disks were debarked and a composite sample was taken considering a circular sector of $30^{\circ}$ in each disk, thus obtaining the sample along all the rings, from the pith to the periphery. The oven-dried $\left(65^{\circ} \mathrm{C}\right)$ samples were milled $(0.25 \mathrm{~mm})$ and digested with $\mathrm{HNO}_{3}$ in a microwave oven. Concentration of $\mathrm{P}, \mathrm{K}, \mathrm{Ca}$ and $\mathrm{Mg}$ were determined by ICP-EOS. Nitrogen was analyzed by combustion, using a Leco analyzer. Based on the observed data and on the findings of other authors $[38,57]$, the independence of nutrient concentration in tree components in relation to stand density, age and site quality was assumed.

\subsection{Stand growth models}

In order to determine the biomass removed by harvesting, dynamic stand growth models and biomass equations were combined. Stand models based on the state-space approach [17] were used to predict changes (transition functions) in the three stand basic variables: number of stems $(N)$, basal area $(G)$ and dominant height $(H o)$, through site index, mortality and basal area growth equations, for a wide range of density management regimes $[1,43]$. In order to use the fitted biomass equations to the tree level, a disaggregation of the stand variables was carried on using the Weibull probability density function and a generalized height-diameter relationship. The Weibull function was estimated using the parameter recovery procedure [26], which provides compatible whole stand and diameter distribution estimates of specific stand attributes [20]. The recovered estimates of the scale and shape parameters were calculated from the values of the mean diameter (the first noncentral moment) and the quadratic mean diameter (the second noncentral moment powered two). It was necessary to fit a species-specific equation to relate the mean diameter to the stand variables estimated by the growth models. Diameter distributions were calculated considering a diameter class width of $5 \mathrm{~cm}$.

The following step in the disaggregation of the stand status was carried out using the generalized height-diameter relationships proposed for these species [24, 47]. As dominant height and quadratic mean diameter are included as explicative variables, these equations can be used irrespective of the plantation age to estimate the height corresponding to the mid point of diameter class. Application of the whole set of equations to each state of the standard stands over time allowed to estimate the stand table before and after thinning, and also the temporal dynamics of nutrient content in tree biomass. A full covering of the explanation of the disaggregation system is provided by Diéguez-Aranda et al. [12].

\subsection{Silvicultural regimes simulated}

Three levels of initial stand density were at first simulated, 1110, 1550 and 2000 stems per ha, but owing to quite similar results of 
Table II. Biomass equations fitted for tree components of maritime pine and radiata pine.

\begin{tabular}{|c|c|c|c|c|}
\hline Pool & Biomass equation & $R_{a d j}^{2}$ & Weighting factor & RMSE \\
\hline \multicolumn{5}{|c|}{ Pinus pinaster } \\
\hline Stem wood & $W=0.3882+0.0115 \cdot d^{2} \cdot h$ & 0.97 & $1 /\left(d^{2} \cdot h\right)^{2,5}$ & 51.22 \\
\hline Stem bark & $W=0.0369 \cdot d^{2.0983} \cdot G^{-0.0551}$ & 0.94 & $1 / d^{4,3}$ & 6.29 \\
\hline Thick branches & $W=3.2019-0.0148 \cdot d^{2}-0.4228 \cdot h+0.0028 \cdot d^{2} \cdot h$ & 0.81 & $1 /\left(d^{2} \cdot h\right)^{2,5}$ & 13.85 \\
\hline Thin branches & $W=0.0978 \cdot d^{2.2881} \cdot h^{-0.9648}$ & 0.83 & $1 / d^{3,9}$ & 4.74 \\
\hline Twigs & $W=0.0019 \cdot d^{2.1537}$ & 0.68 & $1 / d^{5,5}$ & 1.42 \\
\hline Needles & $W=0.0271 \cdot d^{2.5098} \cdot \bar{h}^{-0.6949}$ & 0.83 & $1 / d^{4,4}$ & 5.81 \\
\hline \multicolumn{5}{|c|}{ Pinus radiata } \\
\hline Stem wood & $W=0.0123 \cdot d^{1.6042} \cdot h^{1.4131}$ & 0.96 & $1 / d^{3,8}$ & 53.56 \\
\hline Stem bark & $W=0.0036 \cdot d^{2.6564}$ & 0.92 & $1 / d^{4,0}$ & 11.14 \\
\hline Thick branches & $W=1.937699+0.001065 \cdot d^{2} \cdot h$ & 0.66 & $1 /\left(d^{2} \cdot h\right)^{2,3}$ & 19.95 \\
\hline Thin branches & $W=0.0363 \cdot d^{2.6091} \cdot h^{-0.9417}$ & 0.81 & $1 / d^{4,1}$ & 6.02 \\
\hline Twigs & $W=0.0078 \cdot d^{1.9606}$ & 0.69 & $1 / d^{4,2}$ & 1.49 \\
\hline Needles & $W=0.0423 \cdot d^{1.7141}$ & 0.79 & $1 / d^{4,2}$ & 6.97 \\
\hline
\end{tabular}

where $W$ is the dry weight of the different tree components $(\mathrm{kg}), d$ the diameter at breast height $(\mathrm{cm}), h$ the tree total height $(\mathrm{m}), G$ the stand basal area $\left(\mathrm{m}^{2} \mathrm{ha}^{-1}\right)$, and $\bar{h}$ the average height of the stand $(\mathrm{m})$.

total biomass production (which is much more dependent on thinning intensity) the intermediate value, which is close to the average in the region, was kept as initial spacing.

Five intensities of thinning, 15, 20, 25, 30 and 35\%, defined as the ratio between the accumulated yield from thinnings and the total volume produced throughout the whole rotation [22], were tested. Two thinnings were simulated before the clear-cutting at 30 years for both species. The first thinning (age 15 years) combined line removal (one out of seven rows) with low matrix thinning. The second thinning was carried out at 22 years. In order to get the final intensity of the thinning regime simulated, the type of both thinnings was changed by increasing the proportion of trees removed and decreasing the $S G$ ratio, defined as [16]:

$$
S G=\frac{N_{t h} / N_{b t}}{G_{t h} / G_{b t}}
$$

where $N_{t h} / N_{b t}$ represent the percent of trees removed and $G_{t h} / G_{b t}$ the percent of basal area removed.

Table III gives the quantification of the simulated thinnings and indicates a broad range of thinning types and weights, even if $S G$-ratios below 1 (thinnings from above) were not considered, because this type of management was never present in the area of study. Thinning weight, in terms of basal area removed, ranged from $14 \%$ to $45 \%$.

Those five levels of thinning intensities were matched to five site indexes for these species in the region, from SI 16 to 24 in radiata pine and from SI 12 to 20 in maritime pine, in both cases at a reference age of 20 years, and considering in this case the conventional harvesting of no debarked logs.

Finally, the effects in terms of nutrient removed of four harvesting intensity regimes were simulated: (I) removal of debarked stems, (II) no debarked stems (conventional harvesting), (III) additional removal of thick branches and (IV) whole-tree harvesting. Simulations were done in this case for an average level of thinning intensity (25\%) and for and average site quality (SI 20 and SI $16 \mathrm{~m}$ for radiata pine and maritime pine respectively).

\section{RESULTS}

\subsection{Nutrient concentrations in tree components}

Radiata pine showed higher concentrations of $\mathrm{P}$ and $\mathrm{K}$, and smaller of $\mathrm{Mg}$ than maritime pine and this one has higher concentrations of $\mathrm{Ca}$, except for the needles (Tab. IV). Deficiencies in $\mathrm{P}, \mathrm{Mg}$ and $\mathrm{Ca}$ in needles were found for both species $[8,54]$. Crown fractions of both species, and mainly needles and twigs showed the highest concentrations in all the nutrients, with the following general pattern: Needles $>>$ Twigs $>$ Thin branches $>$ Thick branches $>$ Bark $>>$ Stem wood. An important exception to this rule is the accumulation of $\mathrm{Ca}$ and $\mathrm{Mg}$ in the bark for radiata pine, and also the similar concentrations in $\mathrm{Ca}$ and $\mathrm{Mg}$ in twigs and needles for both species. The ratios $\mathrm{P} / \mathrm{N}$ and $\mathrm{K} / \mathrm{N}$ are 1.4 to 2.8 times higher for radiata pine than for maritime pine in all the components. The ratio $\mathrm{Ca} / \mathrm{N}$ is higher in maritime pine, except for bark and needles. $\mathrm{Mg} / \mathrm{N}$ is also higher in maritime pine, except for wood and bark.

\subsection{Nutrient exports in relation to thinning intensity}

Figures 1 and 2 show the effect of thinning intensity and site quality on the nutrient amounts exported and returned to soil as logging residues due to thinnings and clear-cutting for radiata pine and maritime pine, respectively. The differences among the two species were evident for the conventional harvesting system. Higher amounts of nutrients exported were found in radiata pine except for $\mathrm{N}$ (see Tab. IV). Annual nutrient exports were more than 5 times higher in radiata pine for $\mathrm{P}$ and 1.7 times for $\mathrm{K}$ and $\mathrm{Mg}$. The amounts of $\mathrm{Ca}$ exported in both 
Table III. Values of percentage of trees removed and $S G$-ratio tested depending on thinning intensities for radiata pine and maritime pine.

\begin{tabular}{lcccccccc}
\hline & \multicolumn{4}{c}{ Pinus radiata } & \multicolumn{4}{c}{ Pinus pinaster } \\
\cline { 2 - 8 } Intensity of & \multicolumn{2}{c}{ First thinning } & \multicolumn{2}{c}{ Second thinning } & \multicolumn{2}{c}{ First thinning } & \multicolumn{2}{c}{ Second thinning } \\
\cline { 2 - 8 } thinning & \% of trees removed & $S G$-ratio & \% of trees removed & $S G$-ratio & \% of trees removed & $S G$-ratio & \% of trees removed & $S G$-ratio \\
\hline 15 & 0.31 & 1.54 & 0.26 & 1.82 & 0.30 & 1.54 & 0.26 \\
2.00 & 1.61 & 0.40 & 1.43 & 0.30 & 1.89 \\
25 & 0.39 & 1.37 & 0.31 & 1.39 & 0.45 & 1.32 & 0.35 \\
30 & 0.44 & 1.28 & 0.33 & 1.28 & 0.50 & 1.25 & 0.40 & 1.72 \\
35 & 0.50 & 1.22 & 0.37 & 1.22 & 0.53 & 1.18 & 0.44 \\
\hline
\end{tabular}

Table IV. Average and standard deviation nutrient concentrations $\left(\mathrm{mg} \mathrm{g}^{-1}\right)$ of tree components for the Pinus radiata and Pinus pinaster plantations studied.

\begin{tabular}{|c|c|c|c|c|c|c|c|}
\hline & & Stem wood & Stem bark & Thick branches & Thin branches & Twigs & Needles \\
\hline \multirow{2}{*}{$\mathrm{N}\left(\mathrm{mg} \mathrm{g}^{-1}\right)$} & Pinus radiata & $0.94(0.50)$ & $3.50(0.83)$ & $2.13(0.52)$ & $3.55(0.62)$ & $5.55(0.83)$ & $13.79(1.32)$ \\
\hline & Pinus pinaster & $1.45(0.28)$ & $3.69(2.15)$ & $2.73(0.55)$ & $4.46(1.28)$ & $6.91(1.11)$ & $15.24(3.02)$ \\
\hline \multirow{2}{*}{$\mathrm{P}\left(\mathrm{mg} \mathrm{g}^{-1}\right)$} & Pinus radiata & $0.11(0.15)$ & $0.14(0.18)$ & $0.22(0.18)$ & $0.35(0.18)$ & $0.45(0.24)$ & $0.86(0.21)$ \\
\hline & Pinus pinaster & $0.06(0.03)$ & $0.11(0.04)$ & $0.11(0.03)$ & $0.21(0.04)$ & $0.34(0.03)$ & $0.53(0.07)$ \\
\hline \multirow{2}{*}{$\mathrm{K}\left(\mathrm{mg} \mathrm{g}^{-1}\right)$} & Pinus radiata & $0.71(0.13)$ & $1.91(1.28)$ & $1.46(0.50)$ & $2.05(0.64)$ & $2.82(0.98)$ & $5.47(1.20)$ \\
\hline & Pinus pinaster & $0.70(0.18)$ & $0.85(0.18)$ & $0.93(0.14)$ & $1.73(0.54)$ & $2.48(0.90)$ & $3.44(0.96)$ \\
\hline \multirow{2}{*}{$\mathrm{Ca}\left(\mathrm{mg} \mathrm{g}^{-1}\right)$} & Pinus radiata & $0.32(0.24)$ & $1.08(0.88)$ & $0.55(0.28)$ & $0.69(0.33)$ & $1.38(0.31)$ & $1.69(0.73)$ \\
\hline & Pinus pinaster & $0.53(0.11)$ & $0.93(0.29)$ & $1.48(0.15)$ & $2.52(0.59)$ & $2.68(1.11)$ & $1.46(0.37)$ \\
\hline \multirow{2}{*}{$\operatorname{Mg}\left(\mathrm{mg} \mathrm{g}^{-1}\right)$} & Pinus radiata & $0.20(0.24)$ & $0.55(0.20)$ & $0.40(0.05)$ & $0.47(0.10)$ & $0.62(0.07)$ & $0.75(0.18)$ \\
\hline & Pinus pinaster & $0.26(0.04)$ & $0.41(0.13)$ & $0.59(0.12)$ & $0.74(0.07)$ & $0.95(0.13)$ & $1.04(0.28)$ \\
\hline
\end{tabular}

species were quite similar even if export rates were slightly smaller in low productive maritime pine stands.

Differences among species in the proportion of nutrients exported and returned were also found. For maritime pine, nutrient pools returned as logging residues throughout the whole rotation were quite close to those removed, mainly for $\mathrm{P}, \mathrm{Ca}$ and $\mathrm{N}$. On the contrary, exports in radiata pine stands were considerably higher than returns, being exports of $\mathrm{Mg} 3.0$ times higher than returns. Exports of $\mathrm{P}$ were 2.3 times higher than returns, 1.8 times higher for $\mathrm{Ca}$ and 1.4 times higher for $\mathrm{K}$. In regards to $\mathrm{Ca}$, returns were considerably higher in maritime pine stands both in clear cutting (from $40 \%$ higher for SI 20 and $15 \%$ of thinning intensity to $30 \%$ for SI 12 and the strongest thinning) and in thinnings (close to $25 \%$ higher matching the best site quality and the strongest thinning).

The ratio between removals and returns decreased as thinning intensity increased for all the elements, being this effect more marked in radiata pine stands, as can be seen in Figure 3. This figure is relevant to determine the effect of treatments on proportional losses from the average site index. The increase in thinning intensity implies light reductions of the total amounts of nutrients exported during the whole rotation, specially for radiata pine (10 to $12 \%$ lower for $35 \%$ of thinning intensity in relation to $15 \%$ ), which is due to a reduction of total timber yield.

The distribution in time of nutrient exports has a broad variation due to thinning intensity changes. More intense thinnings promote a progressive recirculation and exportation of nutrients, and the rate of nutrient returned by thinnings in relation to total returns increases from 18-21\% (thinning intensity 15\%) to $38-44 \%$ (thinning intensity $35 \%$ ). For maritime pine stands, nutrient amounts returned to soil are close to two times higher if heavy thinnings are considered instead of slight thinnings.

Higher nutrient efficiency of maritime pine to produce a cubic meter of wood was found: $0.03 \mathrm{~kg} \mathrm{P} \mathrm{m}^{-3}$ instead of 0.1 , $0.27 \mathrm{~kg} \mathrm{~K} \mathrm{~m}^{-3}$ instead of 0.38 , and $0.11 \mathrm{~kg} \mathrm{Mg} \mathrm{m}^{-3}$ instead of 0.14 . As regards $\mathrm{Ca}$, radiata pine shows more efficiency, with $0.17 \mathrm{~kg} \mathrm{Ca} \mathrm{m}^{-3}$ instead of 0.23 in the case of maritime pine.

\subsection{Nutrient exports in relation to site quality}

As a consequence of the different productivity in terms of biomass, nutrient exports are very dependent on site quality. For radiata pine stands the removals of nutrients increase up to 1.6 times in the best sites, and up to 1.9 times for maritime pine. The amounts of nutrient left on site as logging residues are also increased although in a lower extent: 17 to $20 \%$ for radiata pine and 37 to $50 \%$ for maritime pine, depending on the element. The differences between exports and returns are site index-dependant, above all for $\mathrm{P}$ and $\mathrm{Mg}$ in radiata pine stands, with higher differences for the best site qualities. 

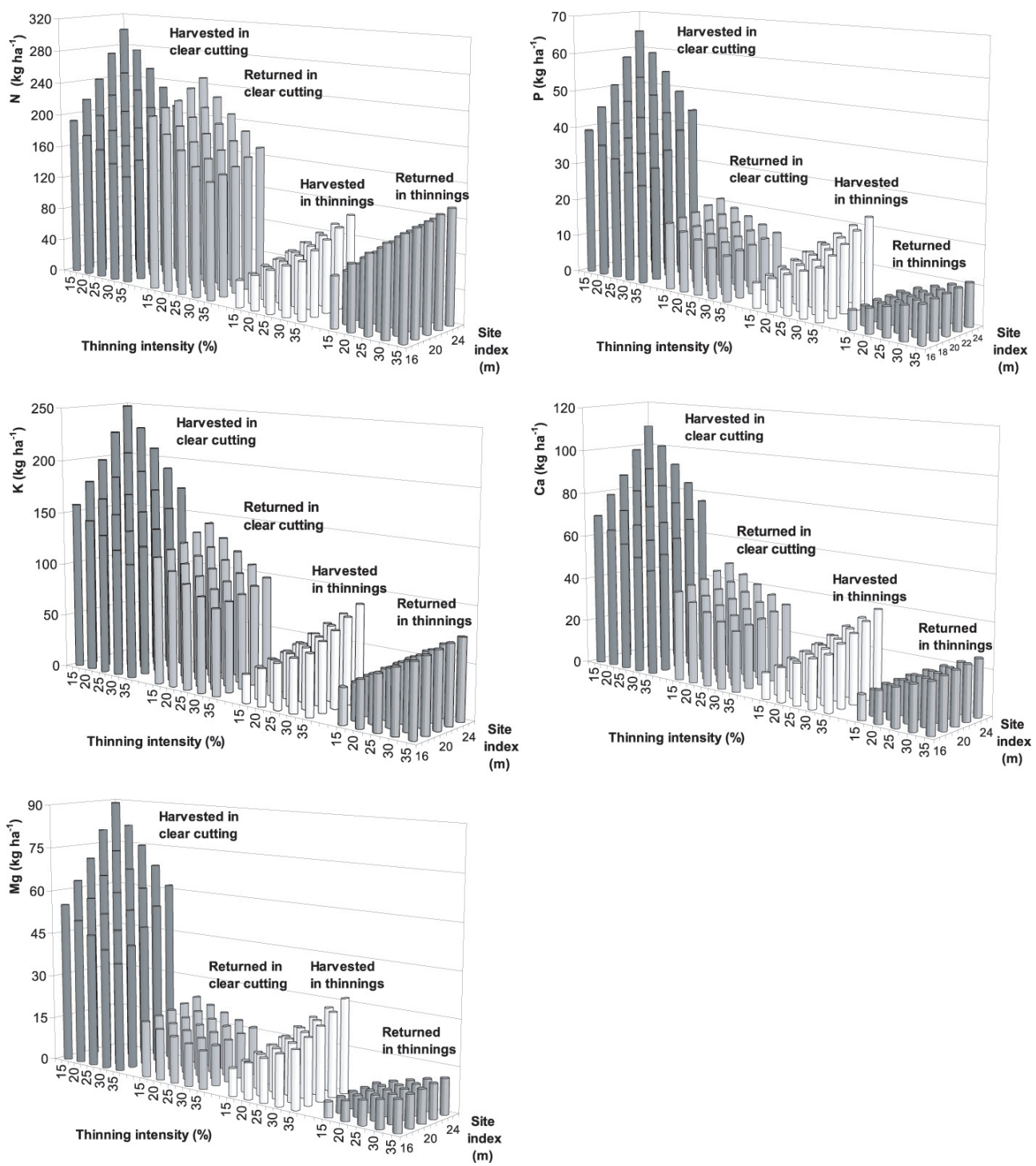

Figure 1. Nutrient removals and nutrient returns to soil as logging residues due to thinnings and clear-cutting as a function of thinning intensity and site quality for radiata pine stands, in the case of conventional harvesting (no debarked wood) and rotation length of 30 years.

\subsection{Nutrient exports in relation to biomass components harvested}

Figure 4 gives the nutrient amounts stored in different biomass components for the whole rotation (considering biomass removed in thinnings and clearfells). This approach allows the comparison in terms of nutrient cost for different harvesting regimes, from stem only harvesting to whole-tree harvesting. The conventional removal of bark (no debarked logs) implies increases of $17,46,33$ and $22 \%$ in the exports of $\mathrm{P}, \mathrm{K}, \mathrm{Ca}$ and $\mathrm{Mg}$ in radiata pine, and 28, 20, 27 and $25 \%$ in the case of maritime pine, in relation to the harvest of debarked stems. The removal of thick branches seems to be less important than bark in relative terms, although it could be important for Ca exports in maritime pine stands. The whole-tree harvesting is obviously the worst option with the highest re- movals, being $\mathrm{K}$ and $\mathrm{Ca}$ the elements subjected to higher increase in both species.

\section{DISCUSSION}

\subsection{Interest and limitations of the estimation methodology}

The simulations considered in this study complement the data presented by Merino et al. [27], who evaluate the amount of nutrients exported under a limited number of harvesting scenarios and compare them with either total or available soil nutrient reserves of pine and eucalyptus. The right estimate of tree biomass and nutrient removals must take into account several parameters such as: (i) stand growth dynamics (i.e. species, site quality), (ii) rotation length [50], (iii) intensity and 

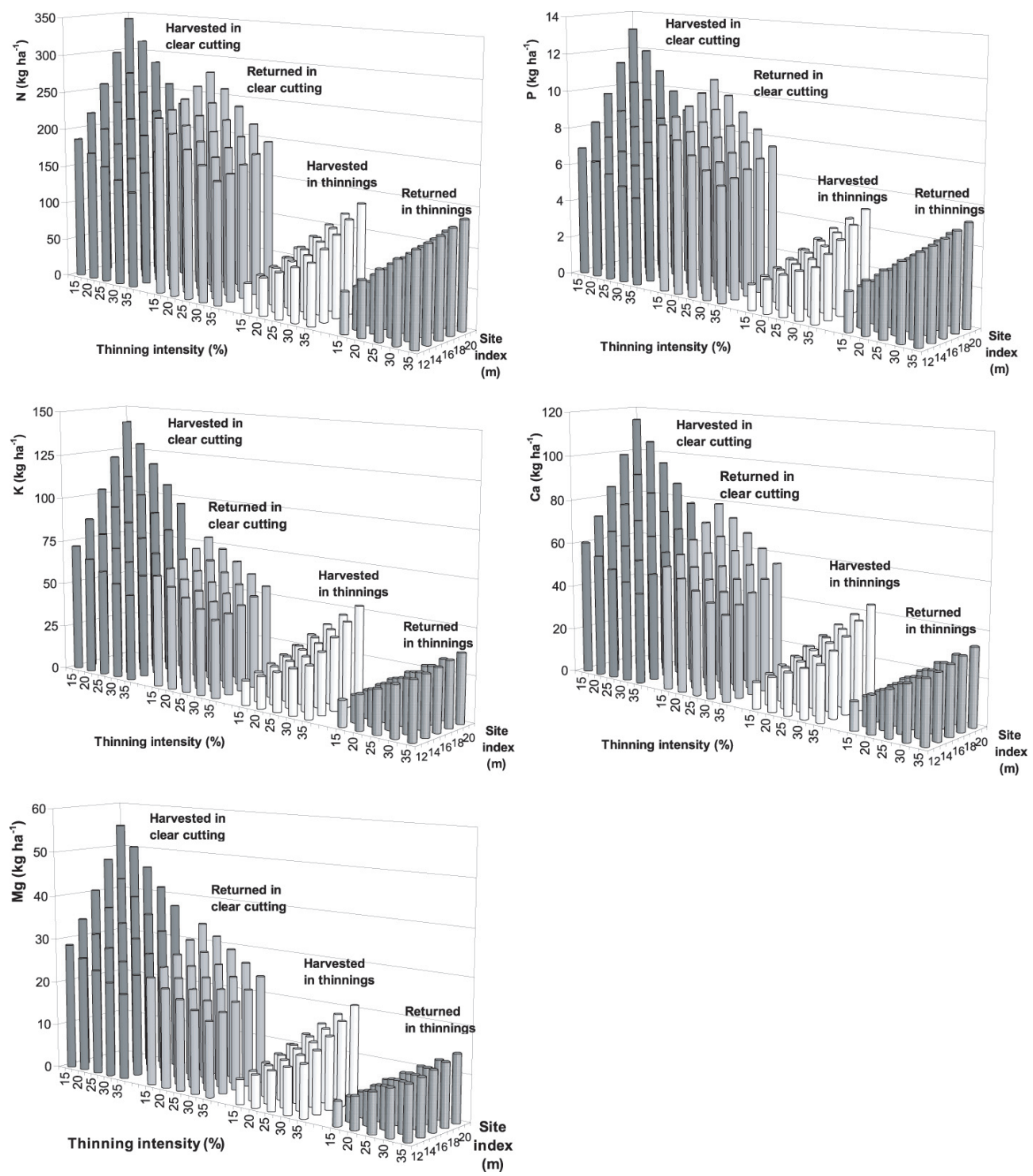

Figure 2. Nutrient removals and nutrient returns to soil as logging residues due to thinnings and clear-cutting as a function of thinning intensity and site quality for maritime pine stands, in the case of conventional harvesting (no debarked wood) and rotation length of 30 years.
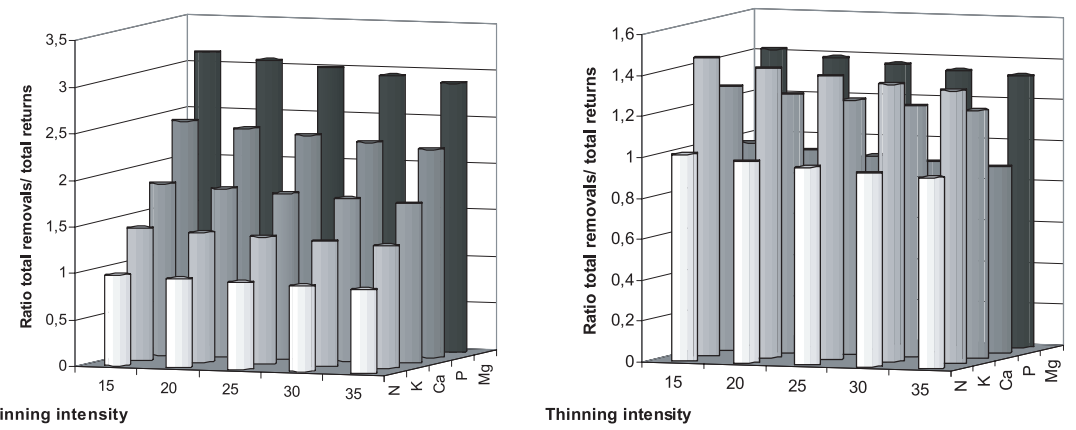

Figure 3. Ratio between total removal/total returns of the five nutrients studied depending on intensity of thinning regime for radiate pine (left) and maritime pine (right), for average site index of each species. 


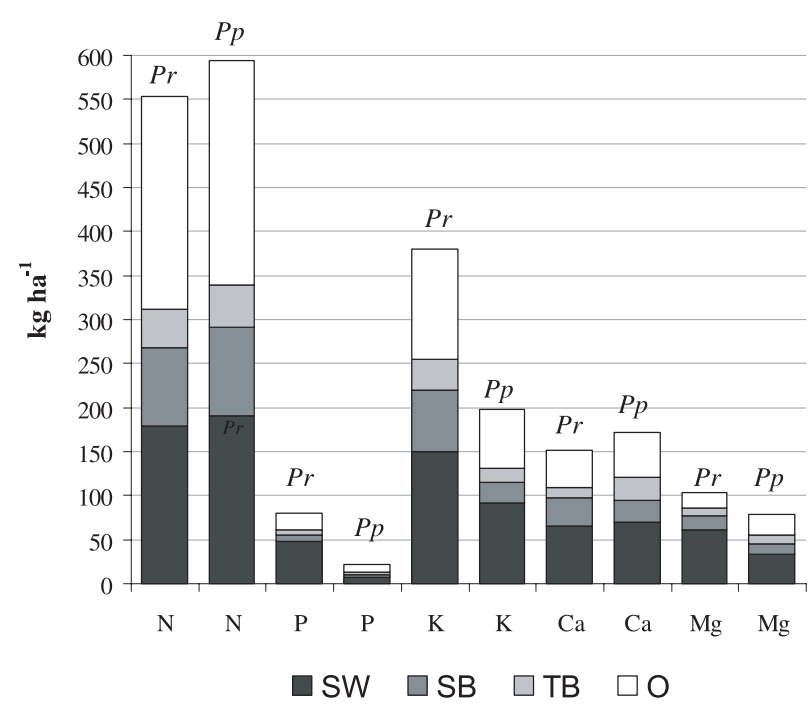

Figure 4. Nutrient amounts from tree biomass exported in radiata pine $(P r)$ and maritime pine $(P p)$ stands for the whole rotation age (thinnings plus clear-cutting) as a function of harvesting operations: Stem wood (SW), stem bark (SB), thick branches (TB) and other components $(\mathrm{O})$. Average SI, thinning intensity of $25 \%$ and rotation length of 30 years were considered.

selectivity of biomass removal $[41,49,55]$, and (iv) harvesting operations $[3,18]$, as well as possible interactions between these factors. The simulations developed in the present study involve all these parameters although, obviously, they have quite limitations. Our study is focused on combining the evolution of tree biomass amounts throughout the rotation to nutrient concentration in tree fractions [2], but other approaches have considered several experimental sites, representing the two extremes of an age gradient $[10,53,56]$. Accurate estimations in these cases are strongly depended on the sampling design and can not be applied to further geographical areas. Other studies try to simplify the calculations by transforming stand volume (from stand inventories and yield tables) into biomass, instead of fitting biomass equations.

Uncertainty in our estimations of nutrient contents is the product of three sources of measurement error: stand diameter and height distributions, biomass equations and nutrient concentrations in tree fractions. Biomass amount and distribution are the parameters which mainly influence the pool of nutrients exported [3] so our simulations concentrate in achieving an accurate estimation of these parameters. In fact, the selection of the equations in the stand growth model and the disaggregation system was done principally to ensure the desirable compatibility between the predictions [12]. Additional information would be useful to improve these estimations and to complete our sampling, e.g. to fit biomass equations and to consider specific concentrations for trees from thinnings. As the crown-tree biomass ratio is density-dependent, considering the large difference in chemical composition between the stem and the crown, the variation of the crown-tree biomass ratio can lead to a change in the nutrient pools [40].
Constant values of nutrient concentration in mature tree components over time and for all site qualities considered were assumed in the present study, according to other authors [3,6]. On the contrary, some authors have found differences regarding stand structure, with concentrations decreasing as stocking increased because of a nutrient dilution throughout larger canopies and root systems $[25,40]$. However we consider that the stand densities for standard management of these species do not involve significant differences as regards nutrient content in tree biomass. Moreover, as thinnings in the simulations happen mainly at the second half of the rotation length, concentration differences are likely to be higher between stands than those due to stocking or age. The direct comparison of the mean concentrations used in this study to $1-2$ years old radiate pine plantations [57] indicates a maximum error of $22.5 \% \mathrm{~N}$, $27.9 \%$ for $\mathrm{P}, 13.3 \%$ for $\mathrm{K}, 24.2 \%$ for $\mathrm{Ca}$ and $6.7 \%$ for $\mathrm{Mg}$.

The use of models considering the spatial pattern of variation of nutrient concentrations inside the bole instead of taking a representative sample from both the hearthwood and the sapwood is a possibility of improvement. This is due to the fact that distribution of nutrient concentrations inside the bole generally reflects retranslocation from older tissues toward the cambial zone, creating higher concentrations in the outer rings [42].

It should be taken into consideration that part of the difference in nutrient exports and returns between an intensive silvicultural regime and a less intensive one, can be due to a lack of appreciation of the quantity of dead branches and needles which are not accounted for by the simulation model used in the study.

\subsection{Implications for the plantation management}

Total above-ground biomass and its distribution among tree components in both species included in this study were within the ranges reported in the literature $[23,29,39,46]$. The large accumulation of $\mathrm{P}$ and $\mathrm{K}$ in the foliage and branches recorded in this work, as compared with large $\mathrm{Ca}$ and $\mathrm{Mg}$ accumulation in the stemwood and bark, is a common feature of most temperate tree species $[18,25]$, even in the case of natural stands [5]. If we consider the estimated annual balance of inputs and outputs of elements in pine plantations in the area $[11,27]$, the threshold of exports for negative budgets in a rotation of 30 years would be: $25 \mathrm{~kg} \mathrm{P} \mathrm{ha}^{-1}, 150 \mathrm{~kg} \mathrm{~K} \mathrm{ha}^{-1}$, $200 \mathrm{~kg} \mathrm{Ca} \mathrm{ha}^{-1}$ and $111 \mathrm{~kg} \mathrm{Mg} \mathrm{ha}^{-1}$. This means that for whole-tree harvesting there would be critical losses for $\mathrm{P}, \mathrm{K}$ and $\mathrm{Ca}$, in the case of radiate pine, and for $\mathrm{K}$ in the case of maritime pine. Even in the traditional harvest of no debarked logs, the exports of $\mathrm{P}$ and $\mathrm{K}$ in radiate pine plantations would be higher than the critical threshold (Tab. V), with a slightly better situation in the well thinned stands. Table $\mathrm{V}$ also shows the comparison of exports to the average nutrient capital of six soils of each species. This matter may partially explain the lower levels of foliar $\mathrm{P}$ in plantations where logging residues are removed [28], and indicates the critical role of $\mathrm{P}$ in the nutrient dynamics of pine stands [45]. The high amounts of soil nitrogen content and nitrogen fixation in the area explain the 
Table V. Total exports compared to critical exports and average soil contents $\left(\mathrm{kg} \mathrm{ha}^{-1}\right)$ for the mean site productivity of Pinus pinaster and Pinus radiata and traditional harvest of no debarked logs.

\begin{tabular}{|c|c|c|c|c|c|c|c|c|}
\hline & \multirow{2}{*}{$\begin{array}{c}\text { Soil } \\
\text { available }\end{array}$} & \multirow{2}{*}{$\begin{array}{l}\text { Soil } \\
\text { total }\end{array}$} & \multicolumn{5}{|c|}{ Total exports for thinning intensities } & \multirow{2}{*}{$\begin{array}{l}\text { Critical } \\
\text { export }\end{array}$} \\
\hline & & & 15 & 20 & 25 & 30 & 35 & \\
\hline \multicolumn{9}{|c|}{ Pinus radiata } \\
\hline$\overline{\mathrm{N}}$ & 4556.5 & 10303 & 281.5 & 274.7 & 267.2 & 259.8 & 252.0 & \\
\hline $\mathrm{P}$ & 49.1 & 2183.8 & 59.3 & 57.6 & 55.8 & 54.0 & 52.1 & 25 \\
\hline K & 179 & 395.9 & 231.8 & 226.0 & 219.8 & 213.6 & 207.1 & 150 \\
\hline $\mathrm{Ca}$ & 520.5 & 1797.7 & 102.1 & 99.6 & 96.9 & 94.2 & 91.4 & 200 \\
\hline $\mathrm{Mg}$ & 86.3 & 4721.9 & 82.4 & 80.2 & 77.8 & 75.4 & 73.0 & 111 \\
\hline \multicolumn{9}{|c|}{ Pinus pinaster } \\
\hline$\overline{\mathrm{N}}$ & & 7405 & 306.1 & 298.2 & 291.8 & 285.5 & 278.6 & \\
\hline $\mathrm{P}$ & 7 & 451.4 & 11.5 & 11.2 & 10.9 & 10.7 & 10.4 & 25 \\
\hline K & 77.5 & 3592 & 121.8 & 118.3 & 115.3 & 112.4 & 109.4 & 150 \\
\hline $\mathrm{Ca}$ & 91.7 & 115.3 & 100.2 & 97.4 & 95.2 & 92.9 & 90.6 & 200 \\
\hline $\mathrm{Mg}$ & 27 & 2795.8 & 47.9 & 46.5 & 45.4 & 44.3 & 43.2 & 111 \\
\hline
\end{tabular}

adequate nutritional conditions that have been found for this element in these plantations, even if the amounts exported are also much higher in the whole-tree harvesting system, as has been already demonstrated [44].

Our results refer only to the direct exportation in the biomass removed, but it is important to consider that the management of coarse woody debris in the area considers usually its elimination through chopping rollers, physical removal or prescribed fire [30]. Potential release of nutrients one year after clear-cut and mechanical incorporation of brash would be as high as $14.2 \mathrm{~kg} \mathrm{~N} \mathrm{ha}^{-1}, 5.4 \mathrm{~kg} \mathrm{P}^{-1}, 72 \mathrm{~kg} \mathrm{~K} \mathrm{Ka}^{-1}$, $36 \mathrm{~kg} \mathrm{Ca} \mathrm{ha}^{-1}$ and $9.8 \mathrm{~kg} \mathrm{Mg} \mathrm{ha}^{-1}$ [33]. Furthermore, nutrient losses by leaching could be promoted where the revegetation process is slowed [13].

We found important changes in nutrient amounts as a function of intensity of thinnings. A low thinning intensity, considered after the thinning weight and thinning cycle, could be related to lower losses of nutrients in the short term [6], but in this case the losses at the clearfelling are likely to increase due to a concentration of logging residues when no uptake is possible. In the case of $\mathrm{N}$, two studies performed in radiate pine plantations in the area have shown processes of $\mathrm{N}$ immobilization after thinning or clear-cut, with mineralization rates strongly depending on the brash management and a net release occurring only where brash was mechanically incorporated into the soil $[33,36]$.

Biomass and nutrient amounts were very dependent on site quality, with the highest exportations for the best sites. Environmental impact due to nutrient removal can be avoided by using compensatory fertilization, especially applying ashes, which are a by-product of the chipboard industries. The amount of ashes to be applied can be easily calculated from the results provided by this article, considering that a single application along the rotation can be enough to compensate for the exports of $\mathrm{Ca}, \mathrm{K}$ and $\mathrm{Mg}$. P deficiency in Pinus radiata is the nutritional problem both most widespread and most responsive to amelioration, especially by superphosphates [52], whose application is necessary to compensate for extractions, since its content in the ashes is low [48].

The decrease in nutrient exports derived from the lengthening of rotations [31] is only significant when these are expanded to uneconomic values for productive plantations. Moreover, progressive problems of timber decayment in the standing trees have been recorded for plantation age in exceed of 50-60 years [43]. Other management options, as the consideration of seed tree regeneration fellings, keeping in place seed bearers for at least 10 years, the promotion of transformation to mixed conifer-broadleaves stands, which apparently enhance the nutrient status of the main species [51] or even a further continuous cover forestry management, derived from a progressive application of thinning from above avoiding a final clearfell [37] can be considered.

\section{CONCLUSIONS}

The amount of nutrients exported in the thinnings and clearcut and returned to the system as logging residues strongly depends on the species, site index, thinning regime and harvesting scenario. Nutrient exports in radiata pine are much higher than those in maritime pine, pointing out the lower site requirements and likelihood of nutrient depletion for the native pine. The data is useful to predict time-term changes in five major nutrients pools in biomass, and denote negative budgets for $\mathrm{P}$, $\mathrm{K}$ and Cain radiate pine plantations. The implementation of an adequate thinning regime and the reduction of intensity in harvestings operations, especially by leaving in place the crown components and even the bark, could enhance the turnover of natural sources of nutrients. Nutrient return by fertilization is necessary to replenish the large amounts of nutrients exported, particularly in the case of radiata pine.

Acknowledgements: Funding for this research was provided by the project AGL2004-07976-C02-01 of the Spanish Ministry of Science. Roque Rodríguez was supported by a research grant from the Spanish Ministry of Education during his stay at the University of Wales, Bangor.

\section{REFERENCES}

[1] Álvarez González J.G., Rodríguez Soalleiro R., Vega G., Elaboración de un modelo de crecimiento dinámico para rodales regulares de Pinus pinaster Ait. en Galicia, Invest. Agr. Sist. Recur. For. 8 (1999) 319-334.

[2] Arthur M.A., Hamburg S.P., Siccama T.G., Validating allometric estimates of aboveground living biomass and nutrient contents of a northern hardwood forest, Can. J. For. Res. 31 (2001) 11-17.

[3] Augusto L., Ranger J., Ponette Q., Rapp M., Relationships between forest tree species, stand production and stand nutrient amount, Ann. For. Sci. 57 (2000) 313-324.

[4] Balboa M., Álvarez González J.G., Rodríguez Soalleiro R., Merino A., Temporal variations and distribution of carbon stocks on aboveground biomass of maritime pine and radiata pine pure stands under different silvicultural alternatives, For. Ecol. Manage. 237 (2006), 29-38. 
[5] Balboa-Murias M.A., Rojo A., Álvarez J.G., Merino A., Carbon and nutrient stocks in mature Quercus robur L. stands in NW Spain, Ann. For. Sci. 63 (2006) 557-565.

[6] Barron-Gafford G.A., Will R.E., Burkes E.C., Shiver B., Teskey R.O., Nutrient concentrations and contents, and their relation to stem growth, of intensively managed Pinus taeda and Pinus elliottii stands of different planting densities, For. Sci. 49 (2003) 291-300.

[7] Blanco J.A., Zavala M.A., Imbert J.B., Castillo F.J., Sustainability of forest management practices: Evaluation through a simulation model of nutrient cycling, For. Ecol. Manage. 213 (2005) 209-228.

[8] Bonneau M., Le diagnostic foliaire, Rev. For. Fr. XL (1988) 19-28.

[9] Bonneau M., Fertilisation des forêts dans les pays tempérés, ENGREF, Nancy, 1995.

[10] Covington W.W., Changes in forest floor organic matter and nutrient content following clear cutting in northern hardwoods, Ecology 62 (1981) 41-48.

[11] Dambrine E., Vega J.A., Taboada T., Rodríguez L., Fernández C., Macías F., Gras J.M., Bilans d'éléments minéraux dans de petits bassins versants forestiers de Galice (NW Espagne), Ann. For. Sci. 57 (2000) 23-38.

[12] Diéguez-Aranda U., Castedo F., Álvarez J.G., Rojo A., Dynamic growth model for Scots pine (Pinus sylvestris L.) in Galicia (northwestern Spain), Ecol. Model. 191 (2006) 225-242.

[13] Fahey T.J, Hill M.O., Stevens P.A., Hornung M., Rowland P., Nutrient accumulation in vegetation following conventional and whole-tree harvest of Sitka spruce plantations in North Wales, Forestry 64 (1991) 271-288.

[14] Fisher R.F., Binkley D., Ecology and management of forest soils, John Wiley \& Sons, New York, 2000.

[15] Fölster H., Khanna P.K., Dynamics of nutrient supply in plantations soils, in: Nambiar E.K.S., Brown A.G. (Eds.), Management of soil nutrient and water in tropical plantation forests, ACIAR Monograph 43, Camberra, 1997.

[16] Gadow K. v., Hui G., Modelling forest development, Kluwer Academic Publishers, 1999.

[17] García O., The state-space approach in growth modelling, Can. J. For. Res. 24 (1994) 1894-1903.

[18] Gonçalves J.L.M., Barros N.F., Nambiar E.K.S., Novais R.F., Soil and stand management for short rotation plantations, in: Nambiar E.K.S., Brown A.G. (Eds.), Management of soil nutrient and water in tropical plantation forests, ACIAR Monograph 43, Camberra, 1997.

[19] Johnson D.W., Todd D.E., Harvesting effects on long-term changes in the nutrient pool of mixed oak forest, Soil Sci. Soc. Am. J. 62 (1998) 1725-1735.

[20] Knoebel B.R., Burkhart H.E., Beck D.E., A growth and yield model for thinned stand of yellow poplar, For. Sci. Monogr. 27 (1986).

[21] Landsberg J.J., Waring R.H., Coops N.C., Performance of the forest productivity model 3-PG applied to a wide range of forest types, For. Ecol. Manage. 172 (2003) 119-214.

[22] Lanier L., Précis de sylviculture, ENGREF, Nancy, 1994.

[23] Lemoine B., Ranger J., Gelpe J., Interprétation et modélisation de la distribution des éléments nutritifs dans les différents compartiments de la biomasse d'un jeune peuplement de pin maritime, Ann. Sci. For. 47 (1990) 101-115.

[24] López C., Gorgoso J., Castedo F., Rojo A., Rodríguez R., Álvarez J.G., Sánchez F., Comparison of generalized height-diameter models for Pinus radiata D. Don in Galicia (North-west Spain), Ann. For. Sci. 60 (2003) 237-245

[25] Maliondo S.M., Mahendrappa M.K., van Raalte G.D., Distribution of biomass and nutrients in some New Brunswick forest stands: possible implications of whole-tree harvesting, For. Can. Maritimes Reg. Inf., Rep. M-X-170 E/F, 1990.
[26] Matney T.G., Sullivan A.D., Compatible stand and stock tables for thinned and unthinned loblolly pine stands, For. Sci. 28 (1982) 161-171.

[27] Merino A., Balboa M.A., Rodríguez Soalleiro R., Álvarez González J.G., Nutrients exports under different harvesting regimes in fastgrowing forest plantations in southern Europe, For. Ecol. Manage. 207 (2005) 325-339.

[28] Merino A., Edeso J.M., Soil fertility rehabilitation in young Pinus radiata plantations from northern Spain after intensive site preparation, For. Ecol. Manage. 116 (1999) 83-91.

[29] Montero G., Ortega C., Cañellas I., Bachiller A., Productividad aérea y dinámica de nutrientes en una repoblación de Pinus pinaster Ait. sometida a distintos regímenes de claras. Invest. Agr. Sist. Recur. For. (1999) Fuera de Serie ${ }^{\circ} 1$.

[30] Montes F., Cañellas I., Modelling coarse woody debris dynamics in even-aged Scots pine forests, For. Ecol. Manage. 221 (2006) 220-232.

[31] Morris D.M., Kimmins J.P., Duckert D.R., The use of soil organic matter as a criterion of the relative sustainability of forest management alternatives: a modeling approach using FORECAST, For. Ecol. Manage. 94 (1997) 61-78.

[32] Olsson B.A., Lundkvist H., Staaf H., Nutrient status in needles of Norway spruce and Scots pine following harvesting of logging residues, Plant Soil 223 (2000) 163-175.

[33] Ouro G., Pérez-Batallón P., Merino A., Effects of sylvicultural practices on nutrient status in a Pinus radiata plantation: nutrient exports by tree removal and nutrient dynamics in decomposing logging residues, Ann. For. Sci. 58 (2001) 411-422.

[34] Page-Dumroese D., Jurgensen M., Elliot W., Rice T., Messer J., Collins T., Meurisse R., Soil quality standards and guidelines for forest sustainability in northwestern North America, For. Ecol. Manage. 138 (2000) 445-462.

[35] Parresol B.R., Additivity of nonlinear biomass equations, Can. J. For. Res. 31 (2001) 865-878.

[36] Pérez-Batallón P., Ouro G., Macías F., Merino A., Initial mineralization of organic matter in a forest plantation soil following different logging residue management techniques, Ann. For. Sci. 58 (2001) $807-818$.

[37] Pommerening A., Murphy S.T., A review of the history, definitions and methods of continuous cover forestry with special attention to afforestation and restocking, Forestry 77 (2004) 27-44.

[38] Ponette Q., Ranger J., Ottorini J.-M., Ulrich E., Aboveground biomass and nutrient content of five Douglas-fir stands in France, For. Ecol. Manage. 142 (2001) 109-127.

[39] Porté A., Bosc A., Champion I., Loustau D., Estimating the foliage biomass and area of maritime pine (Pinus pinaster Ait.) branches and crowns with application to modelling the foliage area distribution in the crown, Ann. Sci. For. 57 (2000) 73-86.

[40] Ranger J., Marques R., Colin-Belgrand M., Flammang N., Gelhaye D., The dynamics of biomass and nutrient accumulation in a Douglas fir (Pseudotsuga menziesii Franco) stand studied using a chronosequence approach, For. Ecol. Manage. 72 (1995) 167-183.

[41] Ranger J., Marques R., Colin-Belgrand M., Nutrient dynamics during the development of a Douglas fir (Pseudotsuga menziesii Mirb.) stand, Acta Oecol. 18 (1997) 73-90.

[42] Rochon P., Paré D., Messier C., Development of an improved model estimating the nutrient content of the bole for four boreal tree species, Can. J. For. Res. 28 (1998) 37-43.

[43] Rodríguez Soalleiro R., Sánchez F., Gorgoso J., Castedo F., López C., Gadow K., Evaluating standard treatment options for Pinus radiata plantations in Galicia (north-western Spain), Forestry 75 (2002) 273-284.

[44] Rolff C., Agren G.I., Predicting effects of different harvesting intensities with a model of nitrogen limited forest growth, Ecol. Model. 118 (1999) 193-211. 
[45] Sánchez-Rodríguez F., López C., Rodríguez-Soalleiro R., Español E., Merino A., Influence of edaphic factors on the productivity of Pinus radiata D. Don plantations in NW Spain, For. Ecol. Manage. 181 (2002) 171-189.

[46] Schlatter J.E., Gerding V., Oñate M.I., Características y variabilidad de sitios con plantaciones adultas de Pinus radiata D. Don en suelos graníticos de las Regiones VIII y IX (Valdivia, Chile), Bosque 19 (1998) 37-59.

[47] Schröder J., Álvarez J.G., Developing a generalized diameter-height model for maritime pine in north-western Spain, Forstwissenchaft. Centr.bl. 120 (2001) 18-23.

[48] Solla-Gullón F., Santalla M., Merino A., Rodríguez Soalleiro R., Nutritional status and growth of a young Pseudotsuga menziesii plantation in a temperate region after application of wood-bark ash, For. Ecol. Manage. 237 (2006) 312-321.

[49] Son Y., Gower S.T., Nitrogen and phosphorus distribution for five plantation species in south-western Wisconsin, For. Ecol. Manage. 53 (1992) 175-193.

[50] Switzer G.L., Nelson L.E., Smith W.H., Effet des raccourcissements des révolutions et de la récolte de la biomasse sur la fertilité des sols, in: Utilisation des engrais en forêt, Colloque, Paris, 1973, pp. $355-381$
[51] Thelin G., Rosengren U., Callesen I., Ingerslev M., The nutrient status of Norway spruce in mixed-species stands, For. Ecol. Manage. 160 (2002) 115-125.

[52] Turner J., Lambert M.C., Nutrition and nutritional relationships of Pinus radiata, Ann. Rev. Ecol. Syst. 17 (1986) 325-350.

[53] White L.L., Zak D.R., Barnes B.V., Biomass accumulation and soil nitrogen availability in an 87-year-old Populus grandidentata chronosequence, For. Ecol. Manage. 191 (2004) 121-127.

[54] Will G.M., Nutrient deficiencies and fertiliser use in New Zealand exotic forests, FRI Bulletin No. 97, Rotorua, New Zealand, 1985.

[55] Yanai R.D., The effect of whole-tree harvest on phosphorus cycling in the northern hardwood forest, For. Ecol. Manage. 104 (1998) 281-295.

[56] Zak D.R., Host G.E., Pregitzer K.S., Regional variability in nitrogen mineralization, nitrification, and overstory biomass in northern Lower Michigan, Can. J. For. Res. 19 (1989) 1521-1526.

[57] Zás R., Serrada R., Foliar nutrient status and nutritional relationships of young Pinus radiata D. Don plantations in northwest Spain, For. Ecol. Manage. 174 (2003) 167-176. 